\title{
'Anorexia': Flesh Speaking Word
}

\author{
Erin Soros
}

L'anorexie, comme maladie de la fin du dix-neuvième siècle, comprend un énorme corps d'écriture. À travers son propre corps et son corps d'écriture, Soros interprète l'anorexie comme un symptôme de la médicalisation de la vie. Le regard médical - avec ses lectures de symptômes et la langue de la maladie - offre à l'anorexique un vocabulaire complet qui lui permet de comprendre son corps qui diminue; il lui donne une technologie de famine; il lui dit ce qu' elle est. À travers l'analyse de la force performative du discours de Judith Butler, Soros argumente que le diagnostique et la maladie de l'anorexie arrivent sur scène simultanément pour écrire la naissance du corps anorexique dans l'existence. Le texte de Soros passe d'une analyse à la troisième personne sur la présentation de l'anorexie comme une maladie, à une description à la première personne sur la subjectification d'une adolescente comme anorexique. Elle décrit comment son corps anorexique a étéécrit dans l'existence par des histoires circulant dans son école secondaire, dans des rapports en classe de psychologie, et dans des films à la télévision. La pratique de citation que la maladie met en oeuvre, où "les comportements et les identités signifient à soi et à l'autre seulement parce qu'ils répètent un code reconnaissable", conduit Soros au jeu de mot provocateur "L'anorexie est une maladie transmissible textuellement."

Given the physical emaciation which defines anorexia nervosa, it is ironic that the disorder has such a full body of writing. The name is cited in thousands of books and articles and thousands of case studies. Each individual performance of the disorder is situated within this body of texts through a complex citational practice which physically performs the name's truth. This citational practice reveals both the name's vulnerability and its productive power. While the doctor says flesh with a name, the anorexic says a name with her flesh.

But how does this saying occur? How does a doctor's name present a disease? How does anorexia nervosa become itself? 
The term "iatrogenic" describes an illness caused by the medical system. Ivan Illich clarifies in Limits to Medicine that while in the narrow sense "iatrogenic" is used only for diseases that "would not have come about if sound and professionally recommended treatment had not been applied" (27), the term more generally describes the multiple afflictions that arrive through the effect of the medical system, what he calls the "medicalization of life." Illich focuses on such issues as injuries received while undergoing medical treatment, contagious diseases caught while staying in a hospital, and unnecessary surgery caused by a doctor's drive to diagnose and cure even when no illness is apparent. But perhaps more significantly, he also argues that "lifelong medical supervision ... turns life into a series of periods of risk, each calling for tutelage of a special kind" (78). As medical knowledge maps the body, the modern subject learns to access herself through a web of medical practises, diagnoses and threats.

I read anorexia nervosa as a symptom of this medicalization of life, a sign of the effects of modern medical tutelage. The anorexic literally embodies a clinical gaze. Although there is some continuity between medieval forms of self-starvation and anorexia, with modern sufferers often describing their acts as holy and their flesh as sinful, the two practices in fact reveal a radical discontinuity. Whereas medieval starvation enacted a religious discourse, modern starvation enacts a medical one. Medical discourse does not simply create a difference in how the behaviour is interpreted, but in how it is performed. Whereas saints flagellated their flesh, anorexics compulsively exercise. Whereas saints wore hairshirts, anorexics encircle their waists with tape measures. Whereas saints allowed only the host or wine to pass through their lips, anorexics count calories, choosing their food by number. Religious practices are replaced by medical ones as anorexics appropriate new techniques, instruments, measurements, words. Modern medical technologies and vocabularies create a distinct form of self-starvation. The practice of measuring the use of calories becomes possible once the precise energy consumed by individual exercises is established. The practice of comparing oneself to an abstract physical norm becomes possible with the development of weight charts cited regularly to students, mothers, patients. The practice of repeatedly weighing oneself becomes possible with the production of the home scale, an instrument created at the beginning of the twentieth century, making no bathroom complete without a piece 
of the doctor's office. As the century proceeds, scales for food become popular in modern kitchens. Lists of nutritional contents become widely available, printed on the obsequious packaging of mass production and marketing. Sugar replacements, amphetamines, laxatives, diuretics, enemas, emetics: this list of anorexic secrets reads like the inside of a doctor's office or of a bathroom medicine cabinet. Modern medicine teaches the anorexic how to control food and measure the body. The broad dissemination of medical knowledge and technology gives anorexia its vocabulary, its tools, its techniques, its success.

But medical discourse and technologies do more than deliver a set of acts to the anorexic. They also tell her what she is. Once someone is diagnosed as sick, she is structured within a fixed set of expected behaviours and roles, given a medical identity:

Usually the danger of routine diagnosis is even less feared than the danger of routine treatment, though social, physical, and psychological torts inflicted by medical classification are no less well documented. Diagnoses made by the physician and his helpers can define either temporary or permanent roles for the patient. In either case, they add to a biophysical condition a social state created by presumably authoritative evaluation. When a veterinarian diagnoses a cow's distemper, it doesn't usually affect the patient's behaviour. When a doctor diagnoses a human being, it does. (Illich 89)

Although Illich describes medicine's influence on a patient's social behaviour, he still posits an ostensively prediagnosed "biophysical condition"- - disease which exists before its definition. What I am interested in exploring, however, is the possibility of a more complex form of medical production, a sliding between diagnosis and disease, between description and prescription, between word and thing. A sliding where sickness does not pre-exist its treatment but arrives with it, diagnosis and disease appearing with their shared name.

This sliding between word and thing is evident in the ambiguity of medical terminology. When a patient first consults a doctor in a hospital, she is said to "present" herself or to "present" the symptoms (Hunter 58). When a doctor later describes this patient's affliction in a pedagogic venue, surgical debriefing or departmental meeting, the 
doctor is described as "presenting" the patient. What does it mean that the same word is used both for the patient's narrative and for the doctor's, both for the appearance of the patient and the description of her? This ambiguous use of the word-one term dividing itself in half as it refers to two ostensibly distinct acts-suggests that the appearance of a diseased patient and the doctor's narration of the disease threaten to fold together. Two times - the present of the patient's appearance and the present of the doctor's description-begin to collapse into one another, each present failing to signify as itself. The doctor "presents" the patient as if his narrative could make her appear, as if her original presentation were not original but given by his delivery, like a past arriving from the future. She presents herself, but is not fully present until the doctor presents her in her absence. His description, folded around this absence, is always in some sense performative, giving that which it describes, presenting what is not yet there.

In Bodies That Matter, Judith Butler analyzes the performative force of discourse, arguing that an acknowledgement of discourse's productive ability does not entail denying the matter of the body. Rather, it demands rethinking materiality as "the effect of power, as powers most productive effect" (2). She elaborates that subjectivity is not outside of or before discourse, but is given through it, through a complex interpellation that is never complete. This conception of power does not negate the possibility of human agency nor does it construct the subject as an individual who freely chooses amongst a number of possible subjectivations. Subjectivation, Butler argues, is not a single act, but a process, a series of ritualized repetitions, each iteration reaffirming the power of discourse as it reveals points of instability and potential failure. Self and body arrive together through a process of discursive accretion: "the formulation of a bodily ego, a sense of stable contour, and the fixing of spatial boundary is achieved through identificatory practices" (14). At stake in such a reformulation of identity and materiality is:

the recasting of the matter of bodies as the effect of a dynamic of power, such that the matter of bodies will be indissociable from the regulatory norms that govern their materialization and the signification of those material effects ... the understanding of performativity not as the act by which a subject brings into being what she/he names, but, rather, as that reiterative power of 
discourse to produce the phenomena that it regulates and constrains ... [and] a rethinking of the process by which a bodily norm is assumed, appropriated, taken on as not, strictly speaking, undergone by a subject, but rather that the subject, the speaking "I," is formed by virtue of having gone through such a process ...

To conceive of discourse as a contagion that somehow infects and determines the actions of individual human subjects or to theorize language as something that imprints itself on an always passive matter is to divest the subject of the agency involved in interpellating a constitutive discourse. Likewise, to construct the subject as a free agent outside of discourse's power is to overlook how the subject itself is created through the discourse it interpellates. Either presumption reasserts a subject/object binary and negates the complexity of subjectivation. Understanding how discourse matters demands thinking of the meridian between subject and object, active and passive, exploring that thin line which manifests itself so evidently in this entity called "anorexia nervosa."

But if one of the productive effects of modern medical discourse is anorexia nervosa, why is it that so many modern subjects are not afflicted with the disease? To say that a discourse is productive is not to imply that it is deterministic nor to claim it as the sole influence in a process of subjectivation. Even the most powerful discourse does not have a monopoly. Moreover, as Butler argues, each discourse has its constitutive outside which always threatens to return, disrupting its process of signification. A performative utterance is always encrypted with potential failure and slippage. A word remains haunted by its inability to deliver a referent. A diagnosis haunted by what it can't say. In the case of anorexia nervosa, multiple discourses matter. The development of the bourgeois family, the rise of consumer capitalism, the effectiveness of modern misogyny and the pervasiveness of the media's promotion of the thin female body-all these structures play instrumental roles in the development of the disease. And given that the mouth is an eroticized boundary in Western culture, a highly charged orifice that opens the self to the other and the other to the self, any disorder involving the mouth is encrypted within a complex psychoanalytic economy. Each anorexic is an individual cathexis of multiple influences. By arguing that medicine has a performative effect, I do not intend to discount other strands of influence or to posit a 
conspiratory intent, but to suggest possible explorations of how medicine interacts with what it says it is not. As a meta-diagnosis-a diagnosis of those who diagnose - an exploration of medicine's productive role will reveal that specialists presenting an illness are not outside its presentation.

"Anorexia Nervosa." Like most adolescent girls, I knew how to pronounce the Latin term. By the early eighties, it had slipped into mainstream vocabulary, functioning as a diagnosis, a compliment, and an insult: "You look anorexic," girls were pre-emptively informed when their bodies refused to develop as quickly or as fully as the others. In these statements, part of the name always went missing. It divided in half, "anorexia" floating by itself, as if waiting for something to arrive. The single word alone enough to signify such a thin referent. The listener knew what it meant when it wasn't all there.

The year I turned sixteen, The Best Little Girl in the World, a novel by the psychologist Stephen Levenkron, was passed from friend to friend at highschool as it hurried towards its status as a best-seller. This novelized case study with its detailed description of anorexic rituals and thought patterns was adapted into a prime time television movie. I watched the movie while eating popcorn, feeding the starving actress by feeding myself. That year I gave a presentation on anorexia to my Psychology class, holding up the inevitable pictures and charts, reading aloud the exercises, measurements, calories. A few months after I presented, I began fasting every second day, folding the week like a paper fan, one day of food matched with one of hunger, presence and absence pressed back to back as I steadily decreased the amount I let in. I carved my flesh away, dividing myself as diligently as I divided the week. Losing half my body weight, I split in two. I presented anorexia.

My self-starvation was not an act, in either sense of the term. It was not an individual action but a form of ritualized repetitions. It was not a fraud, a set of behaviours I could discard if I so desired, but a painful trap I had somehow set and did not know how to escape. The above narrative presents too simply an over-determined experience. My behaviour was established within a complex dynamic of family violence and intergenerational memory, contradictory gender expectations and conflicting desires. The disorder enabled me to negotiate this matrix. I did and did not know what I was doing.

While I remained pleased at my ability to exercise control over my 
body, revising and correcting it like a written assignment, I became ashamed and angry that others could so easily identify me, the transparency of my body telling them how I ate, what I was. But despite this awareness and discomfort with this new identity, I could not stop the vertiginous loss. Just as understanding that gender is a construction does not enable one to step outside its productive power, knowing the name of the disease did not help me to stop saying it with my flesh.

"She's anorexic," people whispered to each other on the bus, delighted and horrified to see a walking specimen. "You are anorexic," students and teachers accused me at school, the word "are" replacing "look," identity replacing resemblance. The declaration was stated as firmly as if saying it would make it so. The act of hailing functioned as a promise or a threat. The constative became performative. The repetition-from doctor, psychologist, nurse, counsellor, teacher, parent, sibling, neighbour, friend-made the name stick. My behaviour became more rigid and extreme as I embodied-or disembodied - the word. But the repetition also suggested that the identity was not as secure as my appearance seemed to reveal. I was in danger of failing to present. I had to be told what I was.

But what was I? Just as Levenkron blurs the genre between case study and novel, my research blurs the boundary between medical rhetoric and memory. I can't access a disorder that has not been interpellated by medical and psychological diagnosis. I can't reach a memory of self-starvation unmediated by a doctor's story. Perhaps this very failure constitutes the truth of the disease.

In this sense, my self-starvation was an act, if not consciously willed as such. I did not create or experience the disorder independent of the descriptions I'd read. I learned the lines and performed them well. This performance was a process of subjectivation: I was not outside the act, choosing and manipulating the part I played, but was given through it. Hilda Bruch, a renowned specialist on anorexia nervosa, bemoans the increase of "copy cat" anorexia or "me too" anorexia, and distinguishes this behaviour from that of the "real" anorexic who arrives on her own (Golden Cage xii). But Butler argues that no such original self-delivery exists. Power is "not the function of an originating will, but is always derivative" (13). Subjectivation is citation. Individual statements, behaviours and identities signify to the self and to the other only because they reiterate a recognizable code. 
The mistake of assuming that the subject is the sole and separate instigator of her acts occurs when the discourse being repeated and the act of repetition are not recognized as such. The subject is seen as originator "to the extent that the citational practice by which he/she is conditioned and mobilized remains unmarked" (13). This citational practice must remain unacknowledged if the etiology of anorexia nervosa is to retain its status as an entity discursively separate from the productive power of its diagnosis.

If constative statements are always in some sense performative, then the doctor isn't outside the patient and diagnosis is never free from the possibility of being copied. Medical discourse is cited through the ritualized repetition of anorexia, each article and book presented through individual acts. Each sufferer hailed with a pathological identity as she repeats what she already knows. Anorexia Nervosa is a textually transmitted disease.

\section{Works Cited}

Bruch, Hilde. Conversations with Anorexics. Eds. Danita Czyzewski and Melanie A. Suhr. New York: Basic, 1988.

Butler, Judith. Bodies That Matter: On the Discursive Limits of 'Sex.' New York: Routledge, 1993.

Hunter, Kathryn Montgomery. Doctor's Stories: The Narrative Structure of Medical Knowledge. Princeton: Princeton UP, 1991.

Illich, Ivan. Limits to Medicine: Medical Nemesis: The Expropriation of Health. London: Boyars, 1976.

Levenkron, Steven. The Best Little Girl in the World. New York: Warner, 1978. 